\title{
Managerial ability and earnings quality: Evidence from Tehran Stock Exchange
}

\author{
Hamid Salehi, Hamdallah Jamshidi Nasrabadolea* and Iman Rameshianfar
}

Department of Accounting, College of graduate studies, Science and Research Branch of Kohgiluyeh and Boyer-Ahmad, Islamic Azad University, Yasouj, Iran

\begin{tabular}{|c|c|}
\hline CHRONICLE & A B S T RACT \\
\hline $\begin{array}{l}\text { Article history: } \\
\text { Received January } 14,2014 \\
\text { Accepted } 10 \text { June } 2014 \\
\text { Available online } \\
\text { June } 152014 \\
\text { Keywords: } \\
\text { Auditing programs } \\
\text { Rotation program } \\
\text { Tehran Stock Exchange }\end{array}$ & $\begin{array}{l}\text { Auditor independence is associated with the independence of the internal/external auditor from } \\
\text { various parties who may have some financial interest in the business being audited. Many } \\
\text { countries have set up different rules forcing firms to change their auditors every few years. This } \\
\text { helps business retain healthy business. This paper presents an empirical investigation to study } \\
\text { the effect of change in auditing system on } 90 \text { selected firms from Tehran Stock Exchange over } \\
\text { the period 2007-2011. Using a regression model developed earlier by Demerjian et al. (2012a) } \\
\text { [Demerjian, P. R., Lev, B., Lewis, M. F., \& McVay, S. E. (2012a). Managerial ability and } \\
\text { earnings quality. The Accounting Review, } 88(2) \text {, 463-498.], the study determines a positive } \\
\text { impact of change in auditor system on business development. }\end{array}$ \\
\hline
\end{tabular}

(C) 2014 Growing Science Ltd. All rights reserved.

\section{Introduction}

Auditor independence is associated with the independence of the internal/external auditor from various parties who may have some financial interest in the business being audited. Many countries have set up a rule, which forces firms to change their auditors every few years (Hambrick \& Mason, 1984). This helps business retain healthy business. Independence of the internal auditor is associated with independence from those whose interests could harm the results of an audit (Ginsberg \& Venkatraman, 1985; Maggina, 2008; Cassell et al., 2012). Specific internal management issues are insufficient risk management, lack of internal controls, and poor governance. The Charter of Audit and the reporting to an Audit Committee normally provides independence from management, the code of ethics of the firm helps reach guidance on independence forms of suppliers, clients, third parties, etc.

*Corresponding author

E-mail addresses: hamdallah.jamshidi@gmail.com (H. Jamshidi Nasrabadolea)

(C) 2014 Growing Science Ltd. All rights reserved.

doi: $10.5267 /$ j.msl.2014.6.028 
Demerjian et al. (2010a) investigated the relationship between managerial ability and earnings quality and reported that earnings quality was related to managerial ability, positively. More specifically, more capable managers were associated with fewer subsequent restatements, higher earnings and accruals persistence, lower errors in the bad debt provision, and higher quality accrual estimations.

Demerjian et al. (2010b) proposed a measure of managerial ability, based on managers' efficiency in building revenues, which was available for a large sample of companies and outperformed existing ability measures. They reported that the measure was strongly associated with manager fixed impacts and that the stock price reactions to chief executive officer (CEO) turnovers were positive (negative) when they evaluated the outgoing CEO as low (high) ability. They also reported that replacing CEOs with more (less) able CEOs was associated with improvements (declines) in subsequent firm performance and concluded with a demonstration of the potential of the measure. They reported that the negative relationship between equity financing and future abnormal returns documented in prior research was mitigated by managerial ability. Specifically, more able managers seemed to utilize equity issuance proceeds, indicating that their more precise measure of managerial ability could allow researchers to pursue studies that were previously difficult to build.

Lee et al. (2004) investigated the relationship between audit committee and board independence and auditor resignations. They reported that audit committee and board of director independence were both associated with the likelihood of an auditor resignation, negatively. Their results also indicated that audit committee independence was positively associated with the quality of the firm's successor auditor. This implies that independent audit committees also played an essential role on reducing the negative effects associated with an auditor resignation.

Lee et al. (2004) presented a comprehensive discussion of the interrelationships among chief financial officers' (CFOs') professional qualifications, SOX Section 404 internal control weakness, CFOs' turnover, CFOs' qualification improvement, and correction of material weaknesses. They reported that companies receiving initial adverse SOX 404 opinions for 2004 had less qualified CFOs. Adverse SOX 404 opinion recipients had more CFO turnover in 2005, and these firms were more likely to hire CFOs having improved qualifications. Their results indicated that simply hiring a new CFO was not related to SOX 404 opinion improvement.

\section{The proposed study}

This paper presents an empirical investigation to study the effect of change in auditing system on 90 selected firms from Tehran Stock Exchange over the period 2007-2011. To select the firms, we excluded the financial, insurance and holding firms, focused only on the firms whose fiscal year did not change over the period of investigation and ticker symbol was active. The study uses the following regression function

$$
\begin{gathered}
A U C H G_{i t}=\beta_{0}+\beta_{1} M G R A B L_{i t-1}+\beta_{2} Z_{\text {ZSCORE }} E_{i t-1}+\beta_{3} C_{A S S H_{i t-1}}+\beta_{4} I N V R E C_{i t-1}+\beta_{5} L E V_{i t-1}+ \\
\beta_{6} G R O W T H_{i t-1}+\beta_{7} A U O P_{i t-1}+\beta_{8} \operatorname{SIZE}_{i t-1}+\varepsilon
\end{gathered}
$$

where $A U C H G$ represents the audit change every four years, $M G R A B L$ states managers' ability, ZSCORE is associated with bankruptcy ratio, $C A C H$ is measured by the amount of available cash divided by total amount of assets. In addition, INVREC states the sum of net cash (INV) plus receivable accounts $(R E C), L E V$ represents total liabilities on total assets, GROWTH is associated with growth rate of total assets. Finally, $A U O P$ is a binary variable, which is one when the auditor's decision is positive and zero, otherwise and Size states the natural logarithm of total assets. Dependent variable is a binary variable, which is one if the firm changes its auditor and zero, otherwise. The ability and efficiency of a firm is measured as follows, 
Efficiency $=\frac{\text { Sales }}{\mathrm{COGS}+\mathrm{SGA}+\mathrm{PPE}+\mathrm{R} \& \mathrm{D}+\mathrm{IA}}$,

where Sales, COGS,PPE, $R \& D$ and $I A$ represent total sales, cost of sold items, book value of equipment, research and development, intangible assets, respectively. According to Demerjian et al. (2012a, 2012b, 2012c), the efficiency can be defined as follows,

$$
\text { Efficiency }_{i}=\beta_{0}+\beta_{1} \text { Ln Assets }_{i}+\beta_{2} \text { MarketShare }_{i}+\beta_{3} \text { CF }_{i}+\beta_{4} \text { LnCash }_{i}+\varepsilon_{i}
$$

where Assets, MarketShare, $C F$ and Cash represent total assets, market share, cash flow divided by total assets and total available cash. In Eq. (3), market share is measured as a ratio of net sales divided by total industry sales. The proposed study measure the rate of bankruptcy based on the Altman method (Altman, 1968), which is developed for Iranian firms as follows,

$Z=0.717 x_{1}+0.874 x_{2}+3.107 x_{3}+0.420 x_{4}+0.998 x_{5}$

where $x_{1}$ to $x_{5}$ represent the ratio of working capital to total assets, net accumulated profit to total assets, ratio of earnings before tax and interest on total assets, ratio of book value of share to total liabilities and the ratio of net sales to total assets, respectively.

\section{The results}

In this section, we present details of our findings on testing the main hypothesis of the survey. Table 1 demonstrates the summary of our findings.

\section{Table 1}

The summary of regression results

\begin{tabular}{|c|c|c|c|c|c|c|}
\hline \multirow{2}{*}{ Variable } & \multirow{2}{*}{\multicolumn{2}{|c|}{$\beta$}} & \multirow{2}{*}{ t-value } & \multirow[b]{2}{*}{ (P-value) } & \multicolumn{2}{|c|}{ Collinearity Statistics } \\
\hline & & & & & Tolerance & VIF \\
\hline MGRABL & \multicolumn{2}{|c|}{0.274} & 7.284 & 0.000 & 0.959 & 1.043 \\
\hline ZSCOR & \multicolumn{2}{|c|}{-0.058} & -1.529 & 0.027 & 0.941 & 1.062 \\
\hline $\mathrm{CASH}$ & \multicolumn{2}{|c|}{-0.099} & -2.44 & 0.015 & 0.827 & 1.209 \\
\hline INVREC & \multicolumn{2}{|c|}{-0.199} & -4.814 & 0.000 & 0.797 & 1.255 \\
\hline LEV & \multicolumn{2}{|c|}{0.074} & 1.823 & 0.069 & 0.828 & 1.208 \\
\hline GROWTH & \multicolumn{2}{|c|}{0.374} & 7.741 & 0.000 & 0.58 & 1.725 \\
\hline AUOP & \multicolumn{2}{|c|}{0} & -0.006 & 0.995 & 0.936 & 1.069 \\
\hline \multirow[t]{2}{*}{ Size } & \multicolumn{2}{|c|}{-0.125} & -2.458 & 0.014 & 0.526 & 1.9 \\
\hline & $\mathrm{F}$ & Sig. & \multicolumn{2}{|c|}{ Durbin-Watson } & \multicolumn{2}{|c|}{ Adjusted $\mathrm{R}^{2}$} \\
\hline Total regression & 31.79 & 0.000 & \multicolumn{2}{|c|}{1.861} & \multicolumn{2}{|c|}{0.334} \\
\hline
\end{tabular}

As we can observe from the results of Table 1, Adjusted R-Square is equal to 0.334, which means the independent variables represent approximately $33 \%$ of the total changes on dependent variable. In addition, F-value is equal to 31.79 with Sig. $=0.000$, which means there is a linear relationship between dependent and independent variables. Durbin-Watson value is equal to 1.861, which means there is no auto-correlation among residuals. The sign of the critical variable, GROWTH, is equal to 0.374 with t-value $=0.000$ and it means that the change on auditing system influences positively on management's performance. Therefore, the main hypothesis of the survey has been confirmed.

\section{Conclusion}

In this paper, we have presented an empirical investigation to study the effects of change on auditing system on the performance of management team on selected firms listed on Tehran Stock Exchange. The proposed study has applied regression technique to verify whether a four-year-change law on change on management team could make any changes on management's capabilities. The results 
have confirmed that the management team could make positive influence on management team. The results of our survey are consistent with findings of Demerjian (2012a, 2012b).

\section{Acknowledgement}

The authors would like to thank the anonymous referees for constructive comments on earlier version of this paper.

\section{References}

Altman, E. I. (1968). Financial ratios, discriminant analysis and the prediction of corporate bankruptcy. The Journal of Finance, 23(4), 589-609.

Cassell, C. A., Giroux, G. A., Myers, L. A., \& Omer, T. C. (2012). The effect of corporate governance on auditor-client realignments. Auditing: A Journal of Practice \& Theory, 31(2), 167188.

Demerjian, P. R., Lev, B., Lewis, M. F., \& McVay, S. E. (2012a). Managerial ability and earnings quality. The Accounting Review, 88(2), 463-498.

Demerjian, P., Lev, B., \& McVay, S. (2012b). Quantifying managerial ability: A new measure and validity tests. Management Science, 58(7), 1229-1248.

Ginsberg, A., \& Venkatraman, N. (1985). Contingency perspectives of organizational strategy: a critical review of the empirical research. Academy of Management Review, 10(3), 421-434.

Hambrick, D. C., \& Mason, P. A. (1984). Upper echelons: The organization as a reflection of its top managers. Academy of Management Review, 9(2), 193-206.

Lee, H. Y., Mande, V., \& Ortman, R. (2004). The effect of audit committee and board of director independence on auditor resignation. Auditing: A Journal of Practice \& Theory, 23(2), 131-146.

Maggina, A. G. (2008). Auditors' switching: An empirical investigation. Global Journal of Business Research (GJBR), 2(1). 